\title{
Beyond intuition
}

Citation for published version (APA):

van der Vleuten, C. P. M. (1996). Beyond intuition. Datawyse / Universitaire Pers Maastricht. https://doi.org/10.26481/spe.19961122cv

Document status and date:

Published: 22/11/1996

DOI:

10.26481/spe.19961122cv

Document Version:

Publisher's PDF, also known as Version of record

\section{Please check the document version of this publication:}

- A submitted manuscript is the version of the article upon submission and before peer-review. There can be important differences between the submitted version and the official published version of record.

People interested in the research are advised to contact the author for the final version of the publication, or visit the DOI to the publisher's website.

- The final author version and the galley proof are versions of the publication after peer review.

- The final published version features the final layout of the paper including the volume, issue and page numbers.

Link to publication

\footnotetext{
General rights rights.

- You may freely distribute the URL identifying the publication in the public portal. please follow below link for the End User Agreement:

www.umlib.nl/taverne-license

Take down policy

If you believe that this document breaches copyright please contact us at:

repository@maastrichtuniversity.nl

providing details and we will investigate your claim.
}

Copyright and moral rights for the publications made accessible in the public portal are retained by the authors and/or other copyright owners and it is a condition of accessing publications that users recognise and abide by the legal requirements associated with these

- Users may download and print one copy of any publication from the public portal for the purpose of private study or research.

- You may not further distribute the material or use it for any profit-making activity or commercial gain

If the publication is distributed under the terms of Article $25 \mathrm{fa}$ of the Dutch Copyright Act, indicated by the "Taverne" license above, 
MB

VAB

327

Beyond Intuition

C.P.M. van der Vleuten 
007 
Beyond Intuition 
ISBN 9052782326

Datawyse / Universitaire Pers Maastricht 


\section{Beyond Intuition}

\section{INAUGURAL LECTURE}

held at the acceptance of the position of professor in education at the University of Maastricht on Friday 22 November 1996

by

Dr. C.P.M. van der Vleuten

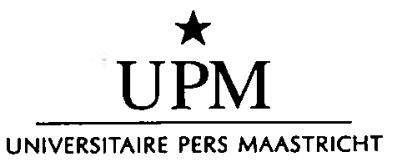


153813474

Universiteilivin:üileak Universite: 1:3articht 


\section{Dear Rector,}

Dear Ladies and Gentlemen,

I was trained as a psychologist in what we now would call a real traditional curriculum. We started with hard core basic sciences in the first year including large portions of anatomy and statistics, making us wonder what psychology was really about and why we had chosen it. Approximately fifty percent of my peers did not survive that first year and had to drop out. In the following years we became smarter. We learned that it was not really necessary to attend the lectures and that the best chance of passing an examination was to delay preparing for it until the last moment. Most exams required reproduction of facts and that's what we did: in the the examination steeplechase we studied from hurdle to hurdle, memorizing and forgetting a huge amount of information at each step. After a number of years I chose to graduate in a research area of personality psychology and psychometrics. I was fortunate in my decision, since I was the only student in the entire class of 75 to make such choice. I automatically became the apprentice of the professor. From that moment on I worked fanatically all and every day of the year and I was totally fascinated by what psychology had to offer as a scientific discipline. My professor was my teacher, my examiner, my mentor, my model and my friend. I learned to critisize academically all and everything in psychology, to mistrust anything which was not submitted to the scrutiny of empirical verification, preferably carried out in a full scientific experiment and replicated several times in subsequent experimental trials. Anyway, I graduated several years after I was supposed to graduate and was lucky that the latter part actually gave me a sound academic background. This was and still is the usual training route and the description I gave is probably appropriate for many people in the audience here 
today, particularly the first part of it. I'm afraid that not many will have shared a similar, lucky last part.

By shere coincidence I came into the field of medical education here at the University of Maastricht. My task was to conduct educational research and to participate in the research of others. I felt at home immediately. The people I worked with, clinicians and biomedical researchers, had exactly the same attitude towards research as I was used to in my own training. It was rewarding to notice that when one is working on a research task, the disciplinary boundaries turn out to be very small and that interdisciplinary collaboration can be very gratifying. However, when I received more tasks in educational development and was required to interact more with the staff in the faculty as teachers, something very odd happened. The academic attitude of the researcher appeared to change when educational issues were discussed. Critical appraisal and scientific scrutiny were suddenly replaced by personal experiences and beliefs, and sometimes by traditional values and dogmas. This was even more so when I was interacting with teachers coming from more traditional educational programmes.

This paradox in attitude is one which has surprised me most, and, to be honest, has also frustrated me most, in my professional career as an educationalist. Hence, I have chosen to deliberate on this topic for my inaugural lecture. We tend to look at education in the way we were trained ourselves. We teach the way we teach, because that is the way we have been taught and that is what we teachers have been doing for many centuries. And look at us, we all have done very well, so why change at all? Yet on the other hand, as highly trained professionals, such as we all are, we are used to grounding our conduct on rational decisions. As a medical doctor, as a lawyer or as an engineer, 
we need first to be licensed to practise at all and once we practice we keep up with the literature, we attend postgraduate courses and we specialize further in our discipline. In the medical profession such a rational approach has been called evidence-based medicine and finds very strong support in the professional community. ${ }^{1}$ To me, this approach reflects no more than a regular academic approach as it is so common in research activities. Research is critical reflection and the quality of research is defined by submitting academic work to the rigorous review of peers. What is the situation in educational practice? I bet hardly anyone in this audience has been licensed as a teacher or even has had limited training before you became involved as a teacher. I know that teachers once appointed hardly read the literature on education. In fact, not all university libraries in the Netherlands have appropriate educational journals in their collections. ${ }^{2}$ A peer review process, so common in research, is out of the question in most educational situations and is considered as interference with someone's autonomy and professional integrity. In conclusion, education is governed by tradition and intuition. We accept the tradition in education because we intuitively believe that we are doing the correct things. We bring our personal and experiential knowledge to our teaching practice and we consider our professional licentiate as a sufficient condition to allow us to practise education.

The central question naturally is: are we doing the correct and rational things? You might already have guessed my answer: in many cases we are not. My central argument is that our knowledge of education is largely based upon intuition and is rather naive. There are so many things in education we intuitively accept and believe, but which turn out to be much more complex or even false when submitted to scientific verification. In the rest of this lecture I will discuss a few of these issues exem- 
plary in order to make a plea for good practice in education defined by a more rational approach. I will subsequently compare problem-based learning with the rational approach and finish with a few characteristics of a rational approach.

\section{Intuitive beliefs and empirical evidence}

In order to illustrate the contrast between intuitive beliefs and empirical outcomes I have chosen three different areas in education, which are central to any training programme. In each I will discuss one or two examples of where our intuitive knowledge turns out to be naive and sometimes totally false. It does not mean that all areas in education have been extensively researched or that all educational knowledge is based on controlled experimentation. Documented experiential evidence, qualitative research, quasi-experimentation and theory development may accumulate scientific knowledge as well, just as medicine does not progress by the clinical trial alone. In all aspects, education is a science like any other.

\section{Conceptions of learning}

In our conception of learning we typically adopt the teacher's perspective: knowledge is in the teacher and merely needs to be transferred to the student. Our fundamental approach is to lecture the student, to orally communicate the information from one individual - the one who has - to a group of individuals the have-nots. Judged by the popularity of lecturing, we apparently assume that this approach is effective. However, empirical evidence clearly shows that an individual cannot concentrate for much more than 15 minutes. ${ }^{3}$ We also know that lectures are often badly attended by the students and that only a few teachers master the skill to engage an audience for a longer period of time. In all, the evidence shows that lectures, particu- 
larly as a dominant didactical method, are poor information carriers.

The teacher perspective on the conception of learning is also reflected in the way we assume the students to handle the information. We pile the information in front of the student from what we think is important from our perspective, assuming that the student knows what to do with it and is able to use it in any other situation. There is massive evidence that this is simply untrue. For example, the role of prior knowledge is a key determinant for how we understand new information. ${ }^{4}$ When new information cannot be built on older information, it can easily be lost. We also have ample evidence that transfer of knowledge from one situation to another is generally very poor. ${ }^{5}$ The more that a new situation resembles an old situation, the better that transfer will be. ${ }^{6}$ This is one of the reasons that learning in context, such as by using problems or cases, is considered important. ${ }^{7}$ If we do not pay attention to specific strategies on how information is assimilated by the student and translated into other and new situations, we may eternally continue to wonder why our students are poor problem-solvers and are unable to use the information they have learned.

With the latter evidence I am referring to only a very small and simplified piece in the advances of cognitive psychology. Cognitive psychological research in recent decades has brought substantial new insights into how learning takes place, also within the different professions such as medicine ${ }^{5}$ or mathematics, ${ }^{8}$ and will have considerable influence on education.

Let me turn to the second area of curriculum construction and curriculum organization. 
Curriculum construction and organization

The way that training programmes are organized is a strongly neglected area in curriculum development. The usual situation is one where a training programme consists of the sum of the individual disciplines. It is up to the individual disciplines to decide what is important or not for the programme as a whole. The result is usually an amalgamate with quite a few biases, depending on the more or less random idiosyncrasies of the individuals within the programme. It is questionable whether an individual or an individual department can oversee the necessities of a curriculum as a whole. ${ }^{9}$ When individual teachers are asked to state their educational objectives, we usually find a tremendous amount of disagreement, even within a single discipline. ${ }^{10}$ It is not surprising that quite a few training programmes have been found to suffer from curriculum overload, hobby horse topics, and duplications of content. ${ }^{11}$ It is up to the student, and usually to the student alone, to digest this all, to assimilate and synthesize it and to integrate it into a body of knowledge and skills necessary to tackle the problems of the later profession.

The organizational framework of most schools in higher education reinforces and maintains this situation. The departmental structure gives usually full autonomy to the department and to the teachers within the department. They can be compared to small kingdoms, each with nearly absolute sovereignty. This situation is extremely difficult to change. These "naturalistic" organizations hardly allow any coordination or educational renewal and have the natural tendency to maintain the status quo. ${ }^{12}$

In curriculum construction, the choice of didactic methods and their planning is hardly ever a matter of deliberate consider- 
ation. Most training programmes are characterized by a full schedule of teaching activities consisting usually of lectures and practicals. The assumption is that scheduled teaching activities will result in equal learning activities. The empirical evidence suggests, however, that this relationship is much more complex. A series of studies have actually shown that learning activities indeed increase when there are not too many teaching activities planned, but beyond a certain level of planned activities the opposite occurs: learning activities decrease despite an increase in teaching activities. ${ }^{13}$ The optimum is reached at approximately $40 \%$ of scheduled time for teaching activities, leaving about $60 \%$ of self-study time. Achievement scores of students actually significantly increase when this balance is reached. ${ }^{14}$ The practical implications are enormous, yet they are very difficult to achieve in most training programmes.

A good training programme would require some consensus on the final objectives of the programme, some interdisciplinary cooperation, some central planning, some clear rules and procedures. However, the way that most educational institutions and curricula are organized will scarcely allow this to happen.

\section{Student assessment}

Student assessment is an area which has developed rapidly over the two last decades, particularly in the various professions such as in medical education. ${ }^{15} \mathrm{~A}$ main item on the agenda has been the design of professionally authentic assessment tools. Student assessment is also an area which is explicitly dominated by intuition, beliefs and misconceptions. Although it is my favourite area, I will not go into the nitty gritty of the psychometric aspects of assessment, and demonstrate the huge decision errors we make with our examinations, or falsify the beliefs that we have about what we think we are measuring 
with our educational tests. I will restrict myself to two more broader educational issues related to assessment.

One does not need much convincing, nor much empirical evidence, to observe a lawful relationship between assessment and education: assessment drives learning. ${ }^{16} 17$ Academic success for the students is defined by the examinations, so that's where they go: the students will do whatever the examination programme tells them to do and will not do whatever the examination program does not reward. For the students, the examination programme is the curriculum; it is the tail wagging the dog. As teachers, however, we are inclined to engage ourselves primarily with the training programme itself, the curriculum, and less with assessment. In curriculum revisions I have seen in practice, assessment always comes last, if at all. However, for the student the assessment program is the curriculum. When the assessment programme does not match the objectives of the educational programme, the assessment programme will prevail. There is no exception; there is no escape.

When we look critically at assessment programmes in educational practice, we can hardly be surprised that we do not achieve the desired higher level educational objectives. As I alluded to in my own training programme, the not uncommon assessment programme consists of a series of hurdles, often testing no more than small facts which could only be reproduced correctly when memorized shortly before. ${ }^{18}$ Students, being normal human beings, are efficient in their approach to tackle these hurdles. They will work hard to pass each of these examinations: they memorize and cram shortly before, take the examination, wipe their hard disk and will quickly go on to the next one. The teacher's assumption is that once the student has passed the examination, he is competent, usually for life, be- 
cause the content of the examination is never repeated again. We know, however, how fast learning curves are subject to decay when the information is not used afterwards and particularly when knowledge has been memorized just for the occasion. ${ }^{19}$ Given the lawful relationship between assessment and education, you will get out of education whatever you are prepared to put into assessment.

Examination programmes are usually there in order to account for the competency of the students: they should guarantee that the competent students succeed and the incompetent students fail. However, this is again something one can seriously challenge. In a series of studies my colleague Dr. Cohen from the University of Groningen demonstrated that the number of students failing a programme, or the number of students having serious delay in their studies is much more influenced by the way we arrange our examinations than by the competency of our students. ${ }^{20}$ For instance, the number of examinations scheduled within a year directly influences the number of students failing the year. Similarly, the more repeat examinations that are organized, the more the student will postpone studying and will suffer delay as a result, irrespective of the student's competency.

\section{Good practice in education}

In summary, what we take for granted in so many instances in education turns out to be quite different when analysed more closely. Sometimes these outcomes are surprising but logical and sometimes totally unexpected and counterintuitive. I could easily continue with illustrations from other educational areas such as selection, faculty development, quality assurance, clinical teaching or apprenticeship learning, etc., and show that what we do in practice is not as logical as we think. To me, good 
educational practice is characterized by a rational approach to education, which resembles no more or no less the approach as we practise it in our professional activities outside education. The rational approach includes the study of literature, experimentation, the consultation of experts, peer review processes of educational activities and outcomes, debates, and all other academic activities which we are so familiar with in these other professional activities. What is propagated as good practice in evidence-based medicine could be just as well translated into evidence-based education, at least as far as I am concerned.

There are three remarks which I need to add immediately in case I give you the wrong idea. First, my plea so far might give the impression that everything is known in education and that we only need to look for the evidence which is available "out there". Naturally, this is nonsense, and rather the opposite is true: there is actually very little that we know. Therefore, in a rational approach experiments and continuous evaluation, including scientific research, are needed. Secondly, not every outcome in educational research is unexpected and dismisses the value of intuition. Quite on the contrary, intuition, "gut feeling", or a "good nose" is highly valuable in any rational approach. However, it should not end there. Thirdly, not everything needs to be based on hard evidence to allow for a rational approach. Too many things are unknown and we cannot base every decision on empiricism. An appropriate reflection, an open debate, a consensus among parties, an evaluation of experiences, are also quite valid elements in a rational approach. These relativizing remarks, once more, point to the fact that education is by no means different from any other scientific area or professional activity. 


\section{Student-centred problem-based learning}

The question arises whether problem-based learning is a rational approach to education. One conclusion is absolutely clear: problem-based learning has certainly not originated from educational research. A few decades ago, an educational ideology was put into practice by a number of idealists who had the guts and the opportunity to realize a few revolutionary ideas, first at McMaster in Canada and later here in Maastricht in the Netherlands and thereafter in many more places. Revolutions have the tendency to go as rapidly as they come. Also in education we have seen a number of them before. ${ }^{21}{ }^{22}$ I am convinced, however, that problem-based learning has survived because of the rationality of its approach.

\section{Problem-based learning in practice}

Before motivating this assertion, let me very briefly explain problem-based learning for those who are new to the field. ${ }^{23}$ Figure 1 contains a week in the life of a medical student in our problem-based learning programme.

Figure 1: A week of a student in a medical problem-based learning programme.

\begin{tabular}{|c|l|l|l|l|l|}
\cline { 2 - 6 } \multicolumn{1}{c|}{ Monday } & Tuesday & Wednesday & Thursday & Friday \\
\hline an & $\begin{array}{l}\text { Communication } \\
\text { and attitude } \\
\text { training }\end{array}$ & Tutorial group & Skills training & $\begin{array}{l}\text { Tutorial } \\
\text { group }\end{array}$ \\
\hline
\end{tabular}


The heart is the tutorial group. Twice a week a group of approximately 8-9 students and one staff member, called the tutor, meet. They have what is called a blockbook consisting of a number of problems or cases related to the content of that unit of the curriculum. Cases are used to ensure a meaningful context for learning. The study of basic sciences and applied sciences are integrated. In one tutorial session the students will analyse a single problem and discuss their prior knowledge related to it. They will subsequently define what they need to know to tackle the problem and they will define their learning objectives. The task of the tutor is to monitor the group process. The tutor is not teaching, but guiding the students, i.e. by asking questions, by making appointments and probing particular topics. After having defined the learning objectives as a group, the students will pursue the required information individually. They will use multiple sources of information and will compare and synthesize that information. In the next tutorial session they will discuss what they found in a way that requires them to demonstrate understanding of the material learned. In our case, tutorial group sessions are held twice a week and a single curriculum unit usually consists of six weeks. In every unit new tutorial groups are formed through randomization: the students have no choice in the composition of the group. This forces the students to work effectively in any team, as they will also have to do in their later career.

Each unit is interdisciplinary in nature and addresses a particular theme, such as for instance fatigue or blood loss. The units are scheduled according to a master plan in which curricular objectives are defined in content areas deliberately arranged in such a way that a number of desirable principles could be achieved. The curricular architecture includes an increasing complexity, a spiral hierarchy of recurring topics, and a transition from normal to abnormal functioning. 
In order to integrate theory and practice maximally an elaborate skills training programme is arranged starting right in the beginning of the first year. The skills programme is integrated with the content discussed in the tutorial groups. In our illustrative week two training sessions are scheduled. Attitude and communication skills, a pressing societal demand for doctors, is also considered important in skills training. In each curricular unit every student will have an encounter with a (simulated) patient. In a safe laboratory environment the student may practise his social skills, and, as the curriculum progresses, can practise applying knowledge in relation to a real (or simulated) patient. The training on Monday morning could, for example, deal with the bringing of bad news to a (simulated) patient with a neurological problem. The second session that week may be a training of a physical procedure.

The same integrative objective is pursued with the health practice contact in the week of our student. Throughout the curriculum a number of these contacts are organized. They may include a tour on an ambulance, a week nursing patients in a hospital, a day in a general practice, etc.

Lectures are also part of the curriculum. However, they are carefully planned and should have a specific additive function to the learning programme, never to replace the tutorial group. They are used to introduce a curriculum unit, to activate prior knowledge, to help students on difficult topics, to provide unique information (e.g. from an invited speaker in the field), etc. On average, approximately two lectures are held per week.

The open space in the week of our student is significant. Problem-based learning requires students to work independently. To facilitate self-study a substantial investment is made 
in providing facilities for students. In addition to a library, a socalled 'study-landscape' has been created. This facility provides a library with multiple copies of all current handbooks, a video and slide library, computer facilities for computer-assisted learning and for other information technology applications (access to library files, $\mathrm{CD}$-rom, word-processing and statistical facilities, the Internet, etc.), copying facilities, and ample space to sit quietly for studying. Invariantly throughout the curriculum approximately 10 to 12 hours per week are scheduled activities; the remaining time is for the student to fill in.

In summary, problem-based learning requires students to acquire knowledge by using problems as a learning context, stimulates self-directed learning for life-long learning and integrates disciplines both horizontally (multiple disciplines integrated with one unit) and vertically (basic and applied sciences; theory and practice are integrated).

\section{Is problem-based learning a rational approach?}

Let me revisit the question whether problem-based learning is a rational approach. I am convinced that if a group of experts in education who - for the sake of argument - had no prior knowledge of problem-based learning were to sit at a sketch board and were asked to plan an ideal educational training method by using their current knowledge of education, they would come very close to something like problem-based learning. Problembased learning combines insights from very many different perspectives. ${ }^{24}$ By placing learning into a context, by focusing on professional problems as a starting point for learning, by integrating disciplines, by merging theory and practice, and by emphasizing problem-solving, principles of cognitive psychology are directly realized. ${ }^{25}$ Adult learning theory postulates that learning by adults is characterized by mutual trust and respect, 
intrinsic interest, self-determined learning, freedom of expression, relating learning to personal experiences, active participation in the learning process and defining one's own learning objectives. ${ }^{26}{ }^{27}$ The similarities with problem-based learning are obvious. A current and prominent philosophical view on human learning, called constructivism, ${ }^{28}{ }^{29}$ claims that knowledge is not an absolute or objective representation of the external world, but that knowledge is interpreted information in the context of experiences. Knowledge is therefore not absolute but "constructed" by the learner. In the construction of knowledge previous knowledge and social interaction are essential elements. The theory stresses the need for collaborative learning, the context-dependency of knowledge and the complexity of knowledge. These concepts are again closely related to the way learning is perceived and operationalized in problem-based learning. Similar arguments could be made for other educational theories such as contextual learning ${ }^{30}$ and situated learning. ${ }^{31}$ All these approaches emphasize actively engaging learners in an enriched contextualized learning environment. It is precisely the way that problem-based learning operates.

A strong argument in favour of the rationality of problem-based learning would be to empirically proof its superiority over more conventional approaches. Although there is still a long way to go, ${ }^{32}{ }^{33}$ there is hard evidence suggesting that problem-based learning leads to more motivated students who have pleasure in studying, ${ }^{34}$ to better self-directed learning skills, to improved attrition rates at similar knowledge levels, ${ }^{36}$ increased clinical skills, ${ }^{37}$ more frequent library use, ${ }^{38}$ and to superior learning styles including less memorization, more retention, better integration of basic and applied sciences. ${ }^{394041}$ I consider it an important task for me and my colleagues to continue to contribute to this evidence in the future. 
So, in summary, although problem-based learning did not originate from a rationalistic and scientific approach to education, I am convinced that its survival and its success is due to its scientifically sound fundaments. Problem-based learning, in my view, is a rational approach.

Is a rational approach a problem-based approach?

Now let me reverse the original question. Is a rational approach a problem-based learning approach? Or, in other words, is problem-based learning the only alternative when adopting a rationalistic approach to education? I' $m$ inclined to answer that question negatively. We should not forget that problem-based learning is but a method of instruction and not a goal in itself. What counts are the principles behind problem-based learning, in particular the ones related to student-centred education: the activeness of the student in acquiring information, the self-responsibility, the learning how to learn, the focus on the application of knowledge, etc. I think there is broad consensus on the relevance of these principles. Fundamental is the acceptance of learning as the centre of education. Professor Wijnen, one of the founding fathers of this university and truly my educational tutor - not my teacher - has made these principles very clear by contrasting teaching programmes with learning programmes. ${ }^{42}$ In Figure 2 these are summarized.

The goal of education is to create a learning environment by using all the insights, information and evidence that we have available. I would not exclude that there are multiple ways to reach this goal and that problem-based learning is only one of them. In the nearly 25 years that we have used problem-based learning at the University of Maastricht and introduced it to the 
Figure 2: Characteristics of learning and teaching oriented programs opposed.

Learning Programs

- Knowledge acquisition

- Student centred

- Dynamic and flexible

- Learning objectives

- Individual

- Reinforces activeness

- Students may discover

- Learning paths are offered

- Teachers ask questions

- Teachers guide students

- Learning is essential

- Formative assessment is essential

- Information finding is essential

- Library and learning facilities are essential

- Demand is essential

- Location independent

- Time independent

- Individual study pace

- Variable study sequence

- Variable content

- Teachers work in collaboration

- Management is essential
Teaching Programs

- Knowledge transfer

- Teacher centred

- Static and rigid

- Teaching objectives

- Uniform

- Reinforces passiveness

- Students are led

- Learning paths are described

- Teachers provide answers

- Teachers direct students

- Teaching is essential

- Summative assessment is essential

- Lectures are essential

- Lecture halls are essential

- Supply is essential

- Location dependent

- Time dependent

- Uniform study pace

- Uniform study sequence

- Uniform content

- Teachers work in isolation

- Departmental or individual autonomy essential

other faculties outside medicine, we have learned that one can not simply copy the system from one discipline to the other. This was quite difficult for us as educationalists. We were sometimes accused of fundamentalism, as the guardians of "the system" and as "educational police". And indeed, where is the rationality if an educational programme becomes a doctrine? Once we were prepared to accept the unique aspects of the 
discipline involved and experimented with new strategies and approaches, the educational innovation was accepted and sustained within these faculties. Similarly, several other medical schools in the Netherlands have successfully changed their program drastically using a number of elements from the above learning environment without copying all aspects of problembased learning.

In conclusion, although it is clear that problem-based learning has strong rationalistic characteristics, problem-based learning is not equal to a rationalistic approach. The rationalistic approach to education is more. Actually, I sometimes call the medical programm of our university a traditional problembased learning programme, because, as in any other school, it is difficult to change things when they have been in place for more than 20 years. A rationalistic approach is dynamic, with continuous evaluation loops, with ongoing changes as a result of these evaluations, with initiatives for new experiments, etc; it is a learning educational organization, constantly in pursuit of innovation. ${ }^{43} \mathrm{~A}$ true rational system would drop problem-based learning as soon as another instructional method was proven to be more effective.

\section{Characteristics of a rational approach}

What are important elements for a rational approach in educational practice? Let me summarize a few essential characteristics.

First and foremost a rational approach to education is one which uses educational evidence. Not using existing and widely available knowledge is simply wasteful and totally unprofessional, yet is quite common practice. ${ }^{44} \mathrm{~A}$ lot of the "educational technology" is available and needs not to be re-invented. Mono- 
graphs and journals are widely available in virtually all professions. In the health sciences alone there are seven international journals on education of good academic standard. A rational approach uses this information.

Essential also for a rational approach is a faculty development programme or a thorough training programme in education. As I referred to before, educational training occurs relatively rarely and if so, it is usually quite limited in extent and scope. Most training programmes consist of teaching specific skills such as lecturing or tutoring, but more is required. What is required is a comprehensive programme for faculty development activities, representing a hierarchical developmental structure. ${ }^{45}$ At the base are professional development activities in which new faculty members should be assisted in understanding and meeting the educational demands of an academic career. It should provide a foundation for getting socialized in the academic community as a basis for their further academic development. Instructional development activities focus on specific teaching skills that facilitate learning. These are of the kind that most existing training programmes cover. Leadership development activities are essential for developing a cadre of faculty members who have special responsibilities as directors, coordinators, mentors, and evaluators. These activities would include programmes for understanding of the planning curricula, and managing complex organizations. Finally, in organizational development activities the focus shifts from the individual teacher to the institution. These activities would involve the creation of policies, procedures and organizational structures that encourage the realization of the mission of the institution and the facilitation of the educational culture committed to continuous quality improvement and innovation. 
A rational approach will require teachers to have an open mind, a different attitude. I am convinced that negative attitudes from teachers toward educational innovations stems more from ignorance than from arrogance. A faculty development programme will help but will not suffice. I previously referred to students as normal human beings looking for the most efficient way for achieving success. Well, university teachers are normal human beings too and are also efficiently striving for success. How is success defined in universities? Naturally by excellence in research. A university teacher spending much time in education is either an idealist or not fit enough for research. One gets through the university ranks by excellent performance in research and not through excellence in education. The attitude of teachers towards education will be difficult to change as long as the imbalance in reward between education and research is maintained as it is.

Part of a rational approach is the use of peer evaluation procedures. Quality of professional activities is best guarded by allowing others to criticize and comment. Peer evaluation in education is meant in its broadest sense. It could, for example, mean the construction of a course using input from various colleagues, also outside one's own discipline. The virtue of interdisciplinary collaboration in education is that one is required to defend the relevance one's own discipline toward other disciplines and to assess others. It could also mean a systematic review of educational products judged by committees. It could also mean systematic procedures to review the content of examinations. In true student-centred systems, the review process would include input from students, and they can be of tremendous value in this regard. ${ }^{46}$ 
Closely related to the previous point is the use of quality assurance principles. A rational educational programme is dynamic and constantly changing. In order to do so, evaluation loops are essential. Scientific knowledge changes very rapidly. In practice, it is much more easy to introduce something into a curriculum than to remove something. In our experience at least every ten years a curriculum is worn out and needs replacement. Evaluation and an organizational framework that allows such operations are essential. In order to deal with the dynamics of a rational approach the management structure of universities should be adapted accordingly. Just as in business, educational organizations should be able to learn and to improve. ${ }^{43}$ Part of the evaluation activities should be educational research. Part of a rational academic approach is to "problemize" one's activities and to reflect upon them. As I said before, there are so many things which are unknown in education, particularly in the many choices we need to make in the daily activities of educational practice. Educational research from within the professions would provide a significant contribution towards the understanding of education in general.

Finally, part of a rational approach would be the consultation of educational experts. Educationalists have specialized in the field and can contribute significantly. A word of caution, however, is in place. In our experience, the best educational service is provided when the educationalist totally understands - or even better, is part of - the profession he works for. To speak the language, to know the professional difficulties, to understand the way of thinking in the profession is of vital importance for the success of the educationalist's contribution. Furthermore, one should avoid delegating too many educational tasks to the educationalists. Being a teacher means more than being involved in the primary process of education. As is evi- 
dent from the hierarchical faculty development model, a professional teacher participates in educational development tasks, faculty development courses, evaluation activities and educational research. The educationalist is there to help and to facilitate and not to replace the teacher's role.

\section{Epilogue}

Ladies and Gentlemen, what I am proposing is nothing new. ${ }^{47}$ My plea is basically to extend our academic and scientific perspective towards education. I am advocating changing our intuitive and traditional approach into a more rational one. I consider this to be my mission and the mission of my department for the future. The characteristics of the academic and scientific approach are quite familiar to us all. It is time that we start seriously using them in education. It is time to go beyond intuition. 


\section{A word of gratitude}

At the end of this public lecture a few words of gratitude are in place.

First, I would like to thank the Faculty of Medicine for recognizing the relevance of my discipline. To support a group of educationalists and to appoint - or, more accurately, reappoint - a professor of education is a token of the faculty's rationalism. Despite my earlier criticism towards the educational attitude of some of the staff, working in the Faculty of Medicine is extremely exciting. Education is definitely on the agenda of the medical school. It is a privilege to work in such a faculty and to develop an educational science from within the profession, in collaboration with people from the profession.

I am grateful to the Members of the University Board. I know how concerned they are with regard to educational innovation in the various faculties of the University of Maastricht. Their support is the backbone for the Maastricht educational enterprise.

Deep gratitude I convey to my educational tutor, Wynand Wijnen. His wisdom, his view on people, and his friendship has inspired me enormously. It will be an impossible task for me to follow in his footsteps.

The fundament for my professional development in education has been formed by my colleagues within the assessment and evaluation project. This interdisciplinary group of physicians and educationalists was a constant source for intellectual stimulation. The thoughts of our intensive debates and our personal friendships are very dear to me. A special thanks to Maarten 
Verwijnen who has influenced me for life with his views on education.

I thank my colleagues from the department of Educational Development and Research. We have an excellent team, both professionally and personally, and I hope we are able to continue the quality of our work.

I thank my colleagues outside the department. To work with people from other disciplines is one of the most gratifying aspects of my work. I thank you for that. A special thanks for my sparring partner in almost everything, Albert Scherpbier. I never hope to miss his friendship and collegiality.

A word of gratitude to my parents also. I am grateful that they can share this day with me. They have unconditionally believed and supported me throughout. From this position, I thank them very much.

There is more to life than work alone. Marianne, Susan, Lotte, Maaike and Benjamin, I am glad that you keep reminding me of this. It is not always easy to put up with a father and husband who is always running to meet the next deadline. I thank you very much for your support. Without you, I would not be standing here.

With this I conclude, and I thank you for your attention. 


\section{References}

1. Evidence-Based Medicine Working Group. Evidence-based medicine: a new approach to teaching the practice of medicine. Journal of the American Medical Association 1992; 268: 2420-5.

2. Scherpbier AJJA, Van der Vleuten CPM, Metz JCM. Wetenschappelijke onderwijs en professionalisering (Scientific education and faculty development). Bulletin Medisch Onderwijs 1994; 13: 30-6.

3. Stuart J, Rutherford RJD. Medical students' concentration during lectures. The Lancet 1978; 312: 514-6.

4. Schmidt HG, De Volder ML, De Grave WS, Moust JHC, Patel VL. Explanatory models in the processing of science text. Journal of Educational Psychology 1989; 4: 610-9.

5. Regehr G, Norman GR. Issues in cognitive psychology: implications for professional education. Academic Medicine 1996; 71: 988-1001.

6. Tulving E, Thomson DM. Encoding specificity and retrieval processes in episodic memory. Psychological Review 1973; 5: 352-73.

7. Schmidt HG. Foundations of problem-based learning: some explanatory notes. Medical Education 1983; 27:422-32.

8. Cobb P, Yackel E, Wood T. A constructivist alternative to the representational view of mind in mathematics education. Journal for Research in Mathematics Education 1992; 23: 2-33.

9. Harden RM, Sowden S, Dunn WR. Educational strategies in curriculum development: the SPICES model. Medical Education 1984; 18: 284-97.

10. Scherpbier AJJA, Schijven MP, van den Wildenberg FAJM. Een onderzoek naar de mening van klinische docenten over het niveau van co-assistenten chirurgie (An investigation of the opinions of clinical teachers on the competence of students in a surgical rotation). In: Pols $\mathrm{J}$, Ten Cate ThJ, Houtkoop E, Pollemans MC, Smal JA, eds. Gezond Onderwijs 4. Houten: Bohn Stafleu van Loghum, 1993: 234-8.

11. Starr P. The social transformation of American Medicine. Cambridge, MA: Harvard University Press, 1982. 
12. Darling-Hammond I, Wise AE, Pease SR. Teacher evaluation in the organizational context: A review of literature. Review of Educational Research 1983, 53: 285-327.

13. Van der Drift KDJM, Vos P. Anatomie van een leeromgeving (Anatomy of a learning environment). Lisse: Swets \& Zeitlinger, 1987.

14. Gijselaers WH, Schmidt HG. Effects of quantity of instruction on time spent on learning and achievement. Educational Research and Evaluation 1995; 1: 183-201.

15. Swanson DB, Norman GR, Linn RL. Performance-based assessment: Iessons from the health professions. Educational Researcher 1995; 24: 5-11.

16. Frederiksen $N$. The real test bias: influences of testing on teaching and learning. American Psychologist 1984; 39: 193-202

17. Newble $D$, Jaeger $K$. The effect of assessments and examinations on the learning of medical students. Medical Education 1983; 17: 165-71.

18. Scott TM, Chafe LL. Critical thinking in medical schools exams. In: Scherpbier AJJA, Van der Vleuten CPM, Rethans JJ, Van der Steeg L, eds. Advances in Medical Education. Dordrecht: Kluwer 1997, in press.

19. Semb GB, Ellis JA. Knowledge taught in school: what is remembered? Review of Educational Research 1994; 64: 253-86.

20. Cohen-Schotanus J. Effecten van curriculumveranderingen (Effect of curriculum changes). [dissertation, with English summary]. Groningen: University of Groningen, 1994.

21. Keller FS. Good-bye, teacher.... Journal of Applied Behavior Analysis 1968; 1: 79-89.

22. Bloom BS. Learning for mastery. Evaluation Comment 1968; 1: 1-12.

23. Snellen-Balendong $H$. Rationale underlying the design of a problembased curriculum. In: Bouhuijs PAJ, Schmidt HG, Van Berkel HJM, eds. Problem-based learning as an educational strategy. Maastricht: Network Publications, 1993: 69-78.

24. Camp G. Problem-based learning: a paradigm shift or a passing fad? Medical Education Online 1996; 1:2. 
25. Norman GR, Schmidt HG. The psychological basis of problem-based learning: a review of the evidence. Academic Medicine 1992; 67: 55765 .

26. Knowles ME. The modern practice of adult education. Cambridge: Prentice Hall, 1980, 57-8.

27. David TJ, Patel L. Adult learning theory, problem based learning, and paediatrics. Archives of disease of childhood 1995; 73: 357-63.

28. Bednar AK, Cunningham D, Duffy TM, Perry JD. Theory into practice: how do we link? In: Duffy TM, Jonassen DH, eds. Constructivism and the technology of instruction: a conversation. Hillsdale: Lawrence Erlbaum, 1992: 17-34.

29. Savery JR, Duffy TM. Problem based learning: an instructional model and its constructivist framework. Educational Technology 1995; 35: 31 7.

30. Coles C. Is problem-based learning the only way? In: Boud D, Feletti $\mathrm{G}$, eds. The challenge of problem-based learning. London: Kogan Page 1991: 295-309.

31. Lave J, Wenger E. Situated learning: legitimate peripheral participation. Cambridge, MA: Cambridge University Press, 1991.

32. Albanese MA, Mitchell S. Problem-based learning: a review of the literature on its outcomes and implementation issues. Academic Medicine $1993 ; 68: 52-81$.

33. Berkson L. Problem-based learning: have the expectations been met? Academic Medicine 1993; 68 (Supplement): S79-S88.

34. Schmidt HG, Moust JHC. Studiebeleving van Maastrichtse medische studenten (Study perceptions of Maastricht medical students). Medisch Contact $1981 ; 49$ : 1515-8.

35. Blumberg P, Michael JA. Development of self-directed learning behaviors in a partially teacher-directed problem-based learning curriculum. Teaching and Learning in Medicine 1992; 1: 3-8. 
36. Verwijnen GM, Van der Vleuten $\mathrm{C}$, Imbos $\mathrm{Tj}$. A comparison of an innovative medical school with traditional schools: an analysis in the cognitive domain. In: Nooman ZH, Schmidt HG, Ezzat ES, eds. Innovation in medical education: an evaluation of its present status. New York: Springer Publishing Company, 1990: 40-9.

37. Scherpbier AJJA, Pols J, Nieuwenhuijzen Kruseman AC, Schaper NC, Verwijnen GM, Van der Vleuten CPM. Interfacultaire vaardigheidstoets Groningen-Maastricht: eerste resultaten (Skills test administered in Groningen and Maastricht: first results). In: Ten Cate ThJ, Dikkers JH, Houtkoop E, Pollemans MC, Pols J, Smal JA, eds. In: Gezond Onderwijs 5. Houten: Bohn Stafleu van Loghum, 1996: 351-7.

38. Rankin JA. Problem-based medical education: effect on library use. Bulletin Medical Library Association 1992; 80: 36-43.

39. Dolmans D, Schmidt HG. Evidence for the advantages claimed for problem-based curricula. The Postgraduate Medical Journal, in press.

40. Coles CR. Differences between conventional and problem-based curricula in their students' approaches to studying. Medical Education 1985; 19: 308-9.

41. Newble DI, Clarke RM. The approaches to learning of students in a traditional and in an innovative problem-based medical school. Medical Education 1986; 20: 267-73.

42. Van der Vleuten CPM, Scherpbier AJJA, Wijnen WHFW, Snellen HAM. Flexibility in learning: a case report on problem-based learning. International Higher Education 1996; 1: 17-24.

43. Otala M. The learning organization. Industry \& Higher Education 1995; 9: 157-64.

44. Nelson MS, Clayton BL, Moreno R. How medical school faculty regard educational research and make pedagogical decisions. Academic Medicine 1990; 65: 122-6.

45. Wilkerson L, Irby DI. Strategies for effecting change in teaching practices: a review of current models. In: Scherpbier AJJA, Van der Vleuten CPM, Rethans JJ, Van der Steeg L, eds. Advances in Mcdical Education. Dordrecht: Kluwer 1997, in press. 
46. Prince CJAH, Visser K. The student as quality controller. In: Scherpbier AJJA, Van der Vleuten CPM, Rethans JJ, Van der Steeg L, eds. Advances in Medical Education. Dordrecht: Kluwer 1997, in press.

47. Miller GE. A perspective on research in medical education. Journal of Medical Education 1970; 45: 694-9. 